\title{
A FUTURE MEXICAN NATIONAL IDENTITY?: LAURA ESQUIVEL'S LA LEY DEL AMOR
}

Meesha Nehru*

RESUMEN: Este artículo es parte de un estudio más largo sobre la representación de género e identidad nacional mexicana en las obras de escritoras contemporáneas posteriores al 68. Se centra en La ley del amor de Laura Esquivel, novela escrita para el mercado global que "se reapropia" de aspectos de la cultura "popular" mexicana y los "hibridiza", trasladándolos a un contexto transnacional. El trabajo muestra como el texto, que apareció justo cuando México estaba redefiniendo su posición en el mundo - después de la firma del trato TLCAN-, es capaz de plantear una versión de identidad nacional que, además de estar fuera de la influencia represiva del legado oficial (estatal), puede resistir las tendencias imperialistas de una cultura "global" y hegemónica. Sin embargo, también critica el hecho de que la novela no crea suficientes espacios dentro de esta visión futura de identidad nacional para todas las situaciones de sujetos posibles.

Palabras Clave: Identidad nacional, Hibridación, Cultura popular, Globalización, Estudios culturales, Poscolonialismo.

From the first chapter of La ley del amor (1995), the reader is made aware of its intention to address directly the issue of Mexican national identity by its reference to the paradigmatic story of the founding of the Mexican nation. Told in the text as the $16^{\text {th }}$ century encounter between Rodrigo, one of Cortes' generals and Citlati an Aztec noblewoman, the story parallels that of Cortes and La Malinche whose meeting, according to the nationalist myth, precipitated the founding of the mestizo Mexican

* The Institute of Latin American Studies (ILAS) at the University of London, Reino Unido (meesha100@hotmail.com). 
nation. The myth, which is often used as the principal starting points for discussions about the formation of the Mexican character, ${ }^{1}$ is reworked in Esquivel's version to show how the main characters have been reincarnated for 14000 lives until their current incarnations as $23^{\text {rd }}$ century Mexican citizens. As an updated version of the national myth that uses science fiction fantasy as well as more traditional romance formats, $\mathrm{La}$ ley del amor re-inscribes it with meanings relevant to the Mexico contemporary to its date of publication. Written a year after the signing of the NAFTA free trade agreement, Laura Esquivel's futuristic science fiction text is a book that can be read as confronting the issue of Mexico's newly found status within a transnational economic, political and cultural context. A political satire, it uses multimedia, ${ }^{2}$ multiple genres and re-articulations of Mexican popular and mass culture, in order to both assert a possible starting point for a future version of collective identity and to negotiate a place for subjectivity within it.

Besides the initial encounter between Rodrigo and Citlati, the rest of the text focuses on the story of Azucena, a twenty-third century astroanalista and her quest to meet up with her alma gemela, a later incarnation of Rodrigo. He disappears from her apartment after just one night of passion and it is only the reunion of these twin souls that will finally restore the law of love across the universe. This law had been disrupted in the $16^{\text {th }}$ century by Rodrigo's violent rape of Citlati, which had resulted in the removal of the top stone from the Aztec temple of love. In order to achieve this union, Azucena has to travel to distant planets, recall her past lives, change bodies twice and overcome the forces of evil represented by Isabel, the Mexican woman candidate for the president of the world. Interspersed with this story, are a host of minor characters who like the principal protagonists undergo regressions to past lives and find that they are all connected in some way. All

1 Octavio Paz, El laberinto de la soledad, Madrid, Cátedra, 1998.

${ }^{2}$ It contains comic strip, and a CD to accompany it. 
these characters also interact with a strange mixture of futurist technological appliances such as the televirtual that allows television images to appear in 3D in the room and references to 'New Age' ideas such as reincarnation, Ying and Yang, and karma.

The complicated and slightly convoluted nature of La ley del amor's plot has meant that it has received a generally negative critical reception, at least in comparison with the runaway success of Laura Esquivel's first novel, Como agua para chocolate (1989). This earlier book, charting the romantic tale of love between a girl and her sister's husband set at the time of the Mexican revolution, was translated into 25 languages, whilst the film version was a box-office smash. La ley del amor uses many of the same features as Como agua para chocolate; examples are its use of so-called 'popular' formats and its principal plot line of passionate romance. Yet, many (mainly North American) critics expressed their disappointment that this novel was not a 'magical realist' text like its predecessor and dismissed its self-conscious blending of multiple media and styles as "silly". ${ }^{3}$ However, it can be argued that some of these accusations levelled against the text are symptomatic of the fact that La ley del amor tends to disturb readers by challenging some of 'global' assumptions about Mexicans and Mexican-ness. For, unlike the pre-industrial Mexicans to be found in the first text, whom critics deem to be fitting representations of citizens of a developing country, La ley del amor displays Mexicans in the $23^{\text {rd }}$ century who have access to, and are totally at ease with, the latest technological advancements and symbols of 'modernity'. By putting Mexicans in roles usually reserved for the protagonists of first-world narratives, ${ }^{4}$ Esquivel's text satirises the relation that present day 'under-developed' Mexico has with

${ }^{3}$ http://www.lasmujeres.com/lauraesquivel/lawreviews.htm (08/06/03).

${ }^{4}$ See intro to M. Barr, Future Females, The Next Generation: New Voices and Velocities in Feminist Science Fiction Criticism, London, Rowman and Littlefield, 2000. 
its 'developed' northern neighbour. The fact that putting Mexicans in such positions unsettles U.S. readers, shows how critics have become accustomed to reading Latin American literature as 'other'. On another level it also reveals and disrupts the imperialist assumptions of the "new world order' globalisation discourse that implies that the (U.S led) 'development' and mass commercialisation of culture will bring the 'backward' 'Third World' nations into line economically with their 'firstworld' counterparts.

Therefore, La ley del amor consists of an assertion of a Mexican national identity within the transnational arena, just at a time when traditional discourses surrounding 'the Mexican' are being challenged by the opening up the country's political and economic borders to the 'globalising' neo-imperialist tendencies of North American free trade. The text reinforces the importance of retaining a sense of the 'national' and the culturally different, without restricting this to narrowly defined nationalistic ideology. By inhabiting, in both form and content, a position 'in-between' both 'national' and transnational discourse, La ley del amor hybridises national culture in a way that theorists, such as García Canclini, Martín-Barbero and Homi Bhabha, have all noted allows resistance to imperialising tendencies whilst at the same time remaining free from the restrictive discourse of 'official nationalism'. ${ }^{5}$ However, as a text that addresses the issue of a Mexican national identity within a transnational, 'post-globalising' context, it remains to be seen how successfully La ley del amor portrays the negotiation of this emancipatory new identity by different subject positions.

${ }^{5}$ Néstor García Canclini, "Cultural Reconversion”, in G. Yúdice, J. Franco and J. Flores [eds.], On Edge: The Crisis of Contemporary Latin American Culture, London, University of Minnesota Press, 1992; J. Martín-Barbero, Communication, Culture and Hegemony: from the Media to Mediations, London, Sage, 1993; H. K. Bhabha [ed.], Nation and Narration, London, Routledge, 1990. 
One of the main ways in which the hybrid national identity that La ley del amor proposes is achieved, is through a 'deterritorialisation" ${ }^{6}$ of national culture and by a reworking of the 'Mexican', through global rather than nationalist discourses. It does this is by changing what is meant by 'popular' culture. References to 'popular' Mexican culture abound in La ley del amor. Not only does the text itself borrow from 'popular' genres such as science fiction fantasy, soap opera, romance and 'New Age' philosophy but the text itself is also littered with other markers of Mexican 'popular' culture such as: comic strip, footballers, mariachis, soap operas and other television programmes. Yet, Claire Louise Taylor says: "[...] the notion in itself of popular culture is certainly contested and the dispute over this categorisation proves central to the workings of La ley del amor." An example of this can be seen by the appearance in the novel of mariachis during all the different time periods. There is even one instance, in a spaceship, of: "[...] mariachis ensayando Amorcito Corazón con un cantante que era la reencarnación de Pedro Infante." Mariachis inhabit an ambiguous position in relation to 'lo popular', which is typical of the other 'popular' referents chosen to appear in the text. They are "both of the people and a mass cultural form." This is because not only do they represent folkloric music, but they have also become symbols of self-parody that are regularly 'sold' to tourists. ${ }^{10}$

They have also gained certain transnational notoriety through the productions of films like: Robert Rodriguez's El Mariachi (1992) and

${ }^{6}$ García Canclini, op. cit., p. 38.

${ }^{7}$ C. L. Taylor, "Body-swapping and Genre-crossing: Laura Esquivel's: La ley del amor", Modern Language Review, no. 97 (2), 2002, pp. 324-335, p. 325.

${ }^{8}$ Laura Esquivel, La ley del amor, Barcelona, Plaza y Janés, 1995, p. 126.

9 Taylor, op. cit., p. 325.

${ }^{10} \mathrm{~W}$. Rowe, and V. Shelling, Memory and Modernity: Popular Culture in Latin America, London, Verso, 1991, p. 71. 
the later Desesperado (1995). Therefore, mariachis are found in a 'hybrid' space, not only emblematic of the Mexican people, but also of what global encoding constitutes as the 'Mexican'. Although Bartra has shown how official state control of culture has maintained a stranglehold on what is considered 'to be of the people' and 'authentically Mexican', ${ }^{11}$ the Mariachis in La ley del amor are an example of a cultural form that has become 'deterritorialised' and therefore free of Mexican state control. ${ }^{12}$ The context of Mariachi culture's representation in the text assures it will be viewed in a transnational perspective as something undoubtedly Mexican but not have its meaning limited by a specific ideology.

In addition, García Canclini demonstrates that the reconfiguration of the 'local', (Mariachis and 'popular' culture) through the 'global', (transnational discourse) is a form of 'cultural reconversion'. This converting of popular culture into a mass form allows it simultaneously to be freed from the patrimony of the state and yet remain a feature of the 'national' that resists being subsumed to dominant discourses. ${ }^{13}$ In $\mathrm{La}$ ley del amor, similar 'reconversions' occur with the numerous references to soap operas and other television programmes. For example the $23^{\text {rd }}$ century character Cuquita, is shown watching El derecho de nacer, ${ }^{14}$ a popular telenovela that was the first ever to be shown in Mexico in the 1960's. As Martín-Barbero has argued the telenovela already occupies a 'hybrid' space. He reads it as "un espacio explícito de entrecruzamiento de la lógica industrial y los requirimientos del mercado con matrices culturales que vienen del mundo popular." 15 The soap opera therefore is not merely a product of the market that imposes transnational values on

${ }^{11}$ See Roger Bartra, “The Mexican Office: Miseries and Splendors of Culture”, Social Text, 1992.

12 See ibid., p. 8.

13 See García Canclini, op. cit., p. 60.

${ }^{14}$ Esquivel, op. cit., p. 91.

15 Martín-Barbero quoted in Taylor, op. cit., p. 327. 
passive spectators. Instead it reworks a mass form to include the "particular' values expressed by the people.

However, as Roger Bartra argued in his 1992 essay 'The Mexican Office', this intermingling of 'lo popular' with 'lo masivo' that occurs in La ley del amor has not always freed culture from state ideology. His critique of Mexican national culture and identity posits that they have been too closely linked to state nationalism, specifically to the policies of Mexico's governing party for 70 years, the PRI. ${ }^{16}$ He states: "Our choice at present is therefore not between a populist option or a transnational proposal: we need only to turn on Mexican television to realise that hegemonic culture has already managed to overcome that contradiction, by imposing on us a deeply jingoistic culture that is aggressively aligned with U.S produced mass culture."17

What Bartra proposes instead is a more fragmented, 'postmodern' national culture that is separate from a (nationalist) way of doing politics. The satirical representation of the PRI in La ley del amor, that accompanies its representation of 'deterritorialised' culture, seems to suggest that Esquivel shares his opinion. Although she does not confine her political commentary to Mexican politicians — Bush the assassinated president of the USA is depicted as a black man from the Bronx - she reserves the most vicious attacks for the government of her own country. For example, the PRI appears in the text as the "Partido de Reivindicación de los Involucionados", ${ }^{18}$ hat is only followed by bitter and resentful lower class people. As well as this, the government is variously represented as overly bureaucratic, and inefficient and just like the "bureaucratic ogre" described by Octavio Paz in his critique of the institutionalised revolution. ${ }^{19}$ In describing a 'national culture' firmly detached from the sphere of politics and as a Mexican novel aimed at a

\footnotetext{
${ }^{16}$ PRI (Partido Revolucionario Institucional, 1929-2000) Bartra, op. cit., p. 3.

17 Ibid., p. 2.

${ }^{18}$ Esquivel, op. cit., p. 33.

19 Paz, op. cit., p. 473.
} 
transnational market, La ley del amor seems to occupy the post-modern space perfect for the kind of cultural critique of nationalism that Bartra suggested.

The text can also be categorised as 'postmodern' because of its use of multiple genres. ${ }^{20}$ It can at once be seen as a 'New Age' romance novel and a science fiction fantasy. These two discourses tend to undermine each other and cause the text to be read as what Jameson has called pastiche, which has consequences for its projected version of Mexican national identity. ${ }^{21}$ The notion of the alma gemela is closely linked to how love is represented in the traditional romance novel. Ryan Prout puts forward the idea that: "[...] Esquivel's novel is [...] determined by the conventions of what Doris Sommer terms the national romance."22 As we have already seen the novel starts with an allusion to the foundational myth of the Mexican nation. This myth was the later Mexican version of what Sommer termed the 'foundational fictions' of 19th century Latin American nations. Stories of 'natural', irresistible love between heterosexual couples, that overcame the wider social constraints in order to achieve a union that would represent the unity of the nation and the identity of its ideal citizens. ${ }^{23}$

At first sight, La ley del amor appears to follow this romantic paradigm, the irresistible love of Azucena and Rodrigo transcends the social obstacle represented by the evil matriarch, Isabel, and ends in happy reunification. However, there are several factors that undermine the "naturalness' of this union and therefore its significance for a national iden-

${ }^{20}$ L. Hutcheon, A Poetics of Postmodernism: History, Theory and Fiction, London, Routledge, 1998, p. 20.

${ }^{21}$ Jameson describes pastiche as empty parody. See M. Hardt, and K. Weeks, The Jameson Reader, Oxford, Blackwell, 2000.

${ }^{22}$ R. Prout, "Cosmic Weddings and a Funeral: Sexuality, Techno-science, and the National Romance in Laura Esquivel's La ley del amor", Tessarae: Journal of Iberian and Latin American Studies, vol. 6, no. 1, 2000, pp. 43 -54, p. 45.

${ }^{23}$ D. Sommer, Foundational Fictions: The National Romances of Latin America, Berkeley, University of California Press, 1991. 
tity. Although, La ley del amor follows the recent tradition of representing the encounter of European man and Indian woman as rape as opposed to the Indian woman's betrayal of her people,$^{24}$ it moves away from implying that the encounter was the foundation of the Mexican nation. For example, Rodrigo is the European who rapes Citlati in the $16^{\text {th }}$ century and who briefly has a passionate love affair with her again in the $23^{\text {rd }}$ century. Yet, his 'twin soul' and the woman that produces his child who, following the paradigm, could be seen to be the first true Mexican, is the white/mestiza, Azucena. This has an ambivalent consequence for Mexican national identity. It destabilizes the traditional identity discourses that suggested that the 'passive' Indian half of Mexican mestizo national identity should be lamented and mourned, ${ }^{25}$ whilst at the same time seemingly sidelining the Indian part altogether.

Nevertheless, some of this ambivalence is displaced by the fact that the romance stereotype, and by proxy the national myth, is constantly undermined as a possible site for the construction of identity. In fact, the whole idea of 'La ley del amor', which underpins the text, is shown to be a self-consciously constructed tool used by the author. This is exemplified when Azucena envisages her reunion with Rodrigo after their long separation: "Ella había soñado con un encuentro de película [...] El fondo musical no podía ser otro que el de Lo que el viento se llevó. Al llegar uno junto al otro se darían un abrazo como el de Romeo y Julieta, como el de Tristán e Isolda, como el de Paolo y Francesca."26 Especially as their reunion ends up very differently, it shows how Azucena's thoughts are conditioned by culturally defined romantic archetypes, similar to those that the novel seems to endorse. Furthermore, the science fiction elements of the text also interrupt the romance paradigm. They do this through the constant appearance of technological

\footnotetext{
${ }^{24}$ W. Neate, Tolerating Ambiguity: Ethnicity and Community in Chicano/ a Writing, New York, Peter Laing, 1998.

25 Samuel Ramos, Octavio Paz, Richard Rodriguez.

${ }^{26}$ Esquivel, op. cit. p. 140.
} 
apparatus' that interfere with the romance stereotype, by challenging its basis on physical attraction. As the characters are able to move freely through different bodies of either gender, not only is the traditional reliance on physical attraction undercut but also the physical body is no longer the main site from which identity is constructed.

The use of science fiction is even more important when looking at the textual representation of a hybrid national identity. By placing Mexico at the forefront of global technological development, it challenges the "assumptions of the New World Order"27 that believe advances such as space travel to be the privilege of the superpowers. As the critic Jameson suggests, futuristic science fiction, usually thought of as the preserve of more developed nations, "confirms the identity and objectives of national projects felt to be determining factors in the course of things yet to come." ${ }^{28}$ In other words, the utopian or dystopian projections of science fiction are intimately connected to the first-world ideology of limitless 'progress'. Mexico, with its failed 'developmental' projects has been traditionally absent or on the periphery of such thinking. ${ }^{29}$ In $\mathrm{La}$ ley del amor however, Esquivel re-appropriates this commercial mass form and its association with 'progress' and re-inscribes it with a particularly Mexican feel.

As well as the mariachis on spaceships, there is an incident when the 'Mexican-ness' of the new technology is affirmed, as the lines of the teletransporters become crossed: "Bueno, pensándolo bien los adelantos de la tecnología en México no eran muy confiables que digamos. Con frecuencia ocurrían ese tipo de accidents, debido a que las líneas aerofónicas se cruzaban o se dañaban."30 This very deliberate allusion to (contemporary) México is another way in which the notion of the

27 Prout, op. cit., p. 45.

${ }_{28}$ Jameson quoted in ibid., p. 46.

${ }^{29}$ Prout compares this futurist novel with the work of Carlos Fuentes who writes about circular time. See ibid., p. 45.

${ }^{30}$ Esquivel, op. cit., p. 79. 
'global' is reworked within the local context. The first-world discourse of progress is reconciled with Mexican traditions just as the first-world science fiction genre is mixed with the Mexican romance. In this way, La ley del amor does not appear to propose a wholesale acceptance of the 'progress' doctrine into Mexican national identity.

The final genre that is invoked and subverted in the novel is that of 'New Age' philosophy. The title 'New Age' is the one given by critics to the representations of karma, ying and yang and reincarnation in the book. However, although the author herself professes to believe in some 'New Age' ideas, ${ }^{31}$ the title does not seem adequate for a description of the use of these features in the text. The term 'New Age' refers to a mostly middle-class, urban and essentially commercial philosophy based on 'Eastern' ideas but in the text the New Age ideas occupy a space between this commercial version and a more specifically Mexican notion of the spiritual. This is shown by the fact that reincarnation, and the notion of circular time implied by karma, are also features to be found in the religions of many indigenous communities. As Claire Louise Taylor says about the futuristic spiritual aid the Ouija cibernética: "[it occupies] an uneasy space of crossover between aids to spiritual fulfilment and commodities in this hyper-modern world." 32 This filtering of 'Mexican' spirituality filtered through 'advanced' technology is an instance of a 'cultural re-conversion' that appears to reconcile a debate between the Latin 'spirit' and the materialism of the North first expounded by the Uruguayan Rodó in his essay Ariel (1900). All in all, in the 'hybrid' vision of Mexican identity that La ley del amor proposes, Mexicans can be seen to be sufficiently 'progressed' and savvy in the ways of globalisation to be able to choose which elements of culture they want to buy into; be they mariachis, soap operas or New Age philosophy. However, this increasingly commodified culture will not be totally sub-

${ }^{31} \mathrm{http}: / /$ www.salon.com/oct96/interview961104.html (08/06/03) .

${ }^{32}$ Taylor, op. cit., p. 325. 
sumed into transnational mass culture, as it will retain an essence of the specifically Mexican.

\section{THE CREATION OF FUTURISTIC SUBJECTIVITIES}

It is in the representation of the negotiation of different subject positions within this 'hybrid' Mexican national identity, that La ley del amor's transgressive potential seems to break down. This is because the way the text handles the issues of gender, sexuality, race and class can be read as sometimes reinforcing traditional and restrictive discourses. Although there is an attempt in the text to reflect 'hybridity', and the interaction between global and local within its depiction of subjective identities, this only seems to produce ambivalent outcomes. In terms of a gendered identity, by including a female protagonist, Azucena, within a text dealing with Mexican national culture, Laura Esquivel is already transgressing the traditional discourses on national identity which Jean Franco says posit "an essentially male" identity. ${ }^{33}$ As well as this, Azucena, a successful astroanalista, ${ }^{34}$ who is an active character and confident with her own sexuality, does not easily fall into the virgen/ puta dichotomy that has long dominated debate about the roles of Mexican women. ${ }^{35}$ However, this just places La ley del amor within the recent tradition of books by Mexican women authors that Debra Castillo describes as "Middle class Mexican women writing about middle class women for middle class Mexican women." ${ }^{36}$ Yet, La ley del amor

33 J. Franco, Plotting Women: Gender and Representation in Mexico, New York, Columbia University Press, 1989, p. xiii.

34 The job of futuristic psychoanalyst alludes to the tradition of (male) psychoanalysts who have tried to describe the Mexican national character, e.g. Samuel Ramos.

35 Paz, op. cit..

36 D. Castillo, Easy Women: Sex and Gender in Modern Mexican Fiction, Minneapolis, University of Minnesota Press, 1998. 
with its futuristic body-swapping takes the positionalities of race, ethnicity and gender within national culture further.

In allowing characters to move freely between 'bodies' of either sex, Esquivel's text makes 'bodily experience' stop being the 'seat of identity'. In this way, the delineation of subject positions also becomes 'hybrid', mid-way between consumer choice and an 'essential' soul. Yet, the mixing of genres in the text creates a certain amount of ambiguity surrounding subjectivity and it is therefore difficult to discern exactly what stance the text is taking. For example, the characters are able to swap sex and to insert microchips into their brains to control their thoughts. Although this tends to undermine the "natural' romance narrative and the whole 'ley del amor' framework, the novel relies on a certain essentialism and hence the demands of la ley in order to construct subjectivity. As Claire Louise Taylor, says: "The status of the subject [...] is ambiguous: on the one side, determinism seems to govern the actions of the self in the guise of the ley del amor, on the other the ambiguous presentation of the characters and their boundary crossings seem to destabilise the notions of organic unity that the ley would demand." ${ }^{37}$ It is probably better then, to read the novel in terms of its possibilities and limitations for subjectivity.

In terms of possibilities, Lisbeth Gant-Britton argues that in describing body-swapping: "The Law of love can be read as a parodic sciencefictional extrapolation importantly pointing toward subversion of embodiment as a means of hegemonic socio-cultural oppression and control." 38 She claims that Esquivel, all be it inadvertently, invites readers to consider the end of discrimination based on skin colour. This may be the case, but why is it that when Azucena first swaps bodies she chooses a blond woman with nice legs? "No sabía cual cuerpo escoger. Había de

37 Taylor, op. cit., p. 334.

${ }^{38}$ L. Gant-Britton, "Mexican Women and Chicanas Enter Futuristic Fiction", in Future Females, The Next Generation: New Voices and Velocities in Feminist Science Fiction Criticism, London, Rowman and Littlefield, 2000, p. 263. 
todos tamaños, colores y sabores. Azucena se detuvo frente al cuerpo de una mujer que tenía unas bellas piernas. Ella siempre había soñado con tener unas piernotas." 39 Azucena, as soon as she acquires these legs, gains instant sexual power. Rather than signifying a possible end to racial discrimination, this body-swapping seems to be an ironic portrayal of Anglo defined images of beauty. This is confirmed by the fact that it is a coyote, the name given to the people that help Mexicans cross the U.S illegally, that aids Azucena's transformation. In this sense, the scene is a critique of technological 'progress', if the results mean that Mexicans perhaps through cosmetic surgery ${ }^{40}$ will become subsumed to globalised images of beauty. To counteract this, the new blonde exterior is contrasted with constant reference to the alma that remains unchanged and entirely 'Mexican'. Gant-Britton expounds that the aspiring to blondness of many Mexican women, especially the stars of telenovelas, which signifies that they have 'made-it' in a transnational context, may symbolise a desire for agency, rather than a desire to be white. Nevertheless, even if this were correct, this appears a very exclusive doctrine, as only those with significant consumer power would be able to buy in to the commodified look. In any case, Azucena's transformation to blonde remains ambiguous for although she retains her 'Mexican' soul within her new body, her brain had already been altered by the insertion of a computer chip, suggesting that the 'soul' itself is not really natural. On the other hand, there is little celebration of brown as a skin colour type, which is surely problematical in a text about Mexican identity.

The fact that Azucena is a cyborg yet retains a connection with the 'spirit-world' in defiance of "Western logocentric futuristic conceptions" 41 seems to be another attempt at positing a 'hybrid' female sub-

${ }^{39}$ Esquivel, op. cit., p. 95.

${ }^{40}$ Science fiction projections are often reflections of contemporary fears Prout, op. cit., p. 47.

${ }^{41}$ Gant Britton, op. cit., p. 267. 
jectivity. Yet, the transgressive nature of this is limited again by an essentialism that although undermined within the wider framework of the novel, is also necessary to give the text internal coherence. This can be seen by the novel's references to maternity and homosexuality. It would seem that body-swapping allows for a reconfiguring of the idea of kinship relationships and motherhood. However, when in the text, Rosalío, a man in a woman's body appears carrying Azucena's child, even gendered language comes under scrutiny. As a friend says to Rosalío, (who is trapped in Azucena's old body and therefore called Ex-Azucena): “CCómo esta eso de que estás embarazado." ${ }^{22}$ Nevertheless, despite this seemingly fluid conception of gender, the man-woman does not give birth to the child and eventually the body is returned to Azucena, the mother of the baby. So, contrary to all the other transgressive ideas that are introduced, such as the notion that women are superfluous to the process of reproduction, the text insists that: "El único ser capaz de implantar el alma dentro de un cuerpo humano es la madre."43

It soon becomes apparent that La ley de amor's constant reference to 'lo femenino' and 'lo masculino' as two complementary halves, shows that the body-swapping only really transgresses biological sex discourses, whilst the gender ones remain intact. This persistence with traditional conceptions of gender is confirmed by the fact that Rosalío, the homosexual character in the novel is represented as a 'femenine' soul trapped in a man's body. He says: "Odio tener cuerpo de hombre [...] Como no me gustan las Mujeres, pues tengo que tener relaciones homosexuales, pero la mayoría de los hombres ;Son unos bruscos!" ${ }^{44}$ Ryan Prout asserts that the death of this 'maternal goon' undermines the subversive potential of the representation of a gay character. ${ }^{45}$ Although Rosalío gives the text 'modern' qualities, his ultimate death is necessary for the

\footnotetext{
${ }^{42}$ Esquivel, op. cit., p. 174.

${ }^{43}$ Ibid., p. 94.

${ }^{44}$ Ibid., p. 65.

${ }^{45}$ Prout, op. cit., p. 47.
} 
reunion of the heterosexual couple and the restoration of love to the universe. This insinuates that there is no space for the alternative sexualities within Esquivel's version of a Mexican national identity.

In conclusion, La ley del amor, challenges 'global' assumptions about the 'Mexican' by portraying future Mexicans that are technologically advanced and developed as well as a Mexican culture that can reworks transnational discourses through the 'popular'. From the 'in-between' of the 'national' and 'transnational' the text posits a 'hybrid' identity that can function in the transnational arena whilst remaining specifically national. In this way, Esquivel's identity has the dual effect of liberating a sense of national identity from restrictive nationalistic ideology and preventing its total subordination to dominant 'global' discourse. Bhabha notes how 'hybrid identities' are a means for building productive alliances. ${ }^{46}$ Yet, La ley del amor with its negative critical reception seems to have failed to build many of these alliances. In terms of its content too, the liberatory potential of the Esquivel's 'hybrid' identity breaks down when looking at subjectivities. Although the subjects of the novel are able to transgress some restrictive discourses, ultimately they fail to break free from the constraints of essentialist thinking. Recourse to determinism in this area undermines the fluidity of identity that any 'hybridity' suggests.

${ }^{46}$ H. Bhabha [ed.], Nation and Narration, London, Routledge, 1994, p. 15. 